4-1-1998

\title{
Clarissa's Treasonable Correspondence: Gender, Epistolary Politics, and the Public Sphere
}

Rachel Carnell

Cleveland State University, r.carnell@csuohio.edu

Follow this and additional works at: https://engagedscholarship.csuohio.edu/cleng_facpub

Part of the Literature in English, British Isles Commons

How does access to this work benefit you? Let us know!

Publisher's Statement

This work remains under copyright @ 2014 Eighteenth Century Fiction, McMaster University, doi: 10.1353/ecf.1998.0030, http://muse.jhu.edu/journals/eighteenth_century_fiction/summary/ v010/10.3.carnell.html

\section{Recommended Citation}

Carnell, Rachel, "Clarissa's Treasonable Correspondence: Gender, Epistolary Politics, and the Public Sphere" (1998). English Faculty Publications. 7.

https://engagedscholarship.csuohio.edu/cleng_facpub/7

This Article is brought to you for free and open access by the English Department at EngagedScholarship@CSU. It has been accepted for inclusion in English Faculty Publications by an authorized administrator of EngagedScholarship@CSU. For more information, please contact library.es@csuohio.edu. 


\section{Clarissa's Treasonable Correspondence: Gender, Epistolary Politics, and the Public Sphere}

Rachel K. Carnell

$\mathrm{I}$

n a letter to Lady Bradshaigh, Samuel Richardson emphasized the importance of generating active debate among his readers. He even went as far as to suggest that the readers themselves may become almost author-like in their participation in the public reception of his novels:

The undecided Events are sufficiently pointed out to the Reader, to whom this Sort of Writing, something, as I have hinted, should be left to make out or debate upon. ... It is not an unartful Management to interest the Readers so much in the Story, as to make them differ in Opinion as to Capital Articles, and by Leading one, to espouse one, another, another, Opinion, make them all, if not Authors, Carpers. ${ }^{1}$

Richardson's fascination with the public debate about his novels and his empowerment of readers to participate in debates about their meaning place him squarely within the eighteenth-century social phenomenon that Jürgen Habermas has described as the public sphere.

Although Richardson obviously did not employ the vocabulary of a twentieth-century social critic, the rational debates and exchanges that

1 Samuel Richardson, letter to Lady Bradshaigh, 25 February 1754, in Selected Letters of Samuel Richardson, ed. John Carroll (Oxford: Clarendon Press, 1964), p. 296. 
his novels generated-through letters, periodical reviews, private conversations, and public discussion in coffee-houses-correspond closely to Habermas's description of the bourgeois public sphere, in which private individuals participated in critical public debate through the universalizing capacity of rational thought. Habermas even refers to the public reception of Richardson's novels, in which "Richardson wept over the actors in his novels as much as his readers did," as part of the cultural context that created the "family's self-image as a sphere of humanitygenerating closeness." This perception of shared humanity permitted rational men of different ranks to engage in public debate "without regard to all preexisting social and political rank." 2

In Habermas's analysis, Richardson belongs not to the political public sphere, in which opponents of the Whig government "raised to the status of an institution, the ongoing commentary on and criticism of the Crown's actions and Parliament's decisions," but to its somewhat tangential stepsister, the literary public sphere. Habermas acknowledges that these two spheres were interconnected and "blended with each other in a peculiar fashion," but he never fully explains how the literary public sphere is connected to the realm of political debate. One of his few observations about the distinction between the two spheres is that "female readers as well as apprentices and servants often took a more active part in the literary public sphere than the owners of private property and family heads themselves." 3

Exactly in what way women and other dependents were active participants in the literary public sphere remains opaque in Habermas's analysis. Their role as readers seems limited to helping bourgeois household heads conceive of themselves as humanized through the sphere of the family: literature and public discussions about literature enable private individuals to see themselves in the universalizing terms of "love, freedom, and cultivation-in a word, as humanity."4 Habermas thus considers the role of literature apolitical, except in its humanizing influence on political players. This strand of thought in a work of social theory first published in 1962 should not surprise us, given that the political basis of the early British novel has only recently been reasserted. ${ }^{5}$ If, however, we develop Habermas's provocative claims about the public sphere

2 Jürgen Habermas, Structural Transformation of the Public Sphere, trans. Thomas Burger (Cambridge: MIT Press, 1989), pp. 50, 48, 54.

3 Habermas, pp. $60,55,56$.

4 Habermas, p. 55.

5 See, for example, Nancy Armstrong, Desire and Domestic Fiction: A Political History of the Novel (Oxford: Oxford University Press, 1987); Michael McKeon, The Origins of the English Novel 1600-1740 (Baltimore: Johns Hopkins University Press, 1987); Carol Kay, Political 
through an analysis of the political discourse of Richardson's fiction, we will comprehend the non-partisan but highly political nature of Richardson's work; we will also be able to appreciate the complex relationship between humanizing morality and political analysis that characterized the eighteenth-century literary public sphere.

\section{ค.้}

The contrast between the eponymous narrator of Richardson's Pamela (1741), who at first expresses her oppression in the politicized terms of "tyranny" and "rebellion," and her "lord and master," Mr B., who wishes to present their relationship as "a pretty story in romance," 6 underscores the novel's liminal position during the mid-eighteenth century: intrinsically political and yet definable as pure romance. Richardson himself repeatedly describes his novel as a warning to women not to marry rakes and a warning to parents not to force their children into marrying against their individual wishes. The novel's contemporary reception certainly reiterated this interpretation: Edward Young, for example, described it as "The Whole Duty of wOMAN."”

This moralistic reception, however, belies the highly politicized discourse of Richardson's fiction. From the start of Richardson's first novel, Mr B. is concerned that Pamela's letters are "treasonable," because she "exposes" or makes public (through her letters to her parents) his "private" attempts to seduce her. Similarly in Clarissa, Lovelace describes the "letters that pass between these ladies" (Clarissa and Anna) as "of a treasonable nature." While both men represent versions of tyrannical patriarchs in the home, both also personify the state-Mr B. as a member of Parliament, Lovelace as a potential inheritor of his uncle's seat in the House of Lords. Further, by having Lovelace liken Clarissa's martyrdom both to that of Lucretia and to that of the Catalans after the English had reneged on their promise of a military alliance under the terms of the Treaty of Utrecht (1713), Richardson marks her tragedy as directly political in a way that challenges Habermas's view of the literary public sphere as merely humanizing. ${ }^{9}$

Constructions: Defoe, Richardson, and Sterne in Relation to Hobbes, Hume, and Burke (Ithaca: Cornell University Press, 1988).

6 Samuel Richardson, Pamela, or Virtue Rewarded ( 2 vols), ed. M. Kinkead-Weekes (London: Dent, 1962), 1:20. References are to this edition.

7 Quoted in Duncan Eaves and Ben Kimpel, Samuel Richardson: A Biography (Oxford: Clarendon, 1971), p. 287.

8 Samuel Richardson, Clarissa or the History of a Young Lady, ed. Angus Ross (London: Penguin Books, 1985), p. 573. References are to this edition.

9 Richardson describes Clarissa holding "up to Heaven, in a speechless agony, the innocent licence 
Notwithstanding the obvious political language in the novel, the bulk of twentieth-century criticism of Clarissa has focused less on the political context of the novel than on Richardson's skill in describing character or on the poststructural demeanour of the text. ${ }^{10}$ In the last decade or so, the need for a more specific political analysis of Richardson's work has become increasingly apparent. While Terry Castle and Terry Eagleton have pointed out that Clarissa must be understood in terms of the politics of rape, they do not provide the precise historical context through which to understand the novel's own discourses about gender and political power. ${ }^{11}$ While Nancy Armstrong brilliantly analyses the ways in which Richardson's domestic fiction obscures its political comments about class differences as "gender came to mark the most important difference among individuals," her work does not fully address the fact that many political debates during this period would have occurred under the guise of domestic scenarios. ${ }^{12}$ Although she does not

(which she has in her own power); as the poor distressed Catalans held up their English treaty" (p. 887).

10 Cynthia Griffin Wolff focuses on Richardson's universal description of "character under stress" rather than the historical context that might have caused the structural development of complex novelistic characters. Richardson and the Eighteenth-Century Puritan Character (Hamden, Conn.: Shoe String Press, 1972). Lawrence Stone uses the example of Clarissa as "literary evidence" of "a prolonged public argument during the late seventeenth and eighteenth centuries about a child's freedom of choice of a marriage partner." The Family, Sex and Marriage in England 1500-1800 (New York: Harper and Row, 1977), pp. 280-81. While Richardson's work accords with the sociological evolution that Stone describes, to consider domestic scenarios in literature merely as mirrors of actual life experience belies the rich interplay of symbolic nuance in any eighteenth-century discussion of family structure. Tony Tanner offers a Lacanian reading of the patriarchal Harlowe household, Adultery in the Novel (Baltimore: Johns Hopkins University Press, 1979). The possibility that Lacan's theory offers for contextualizing family dynamics into their social and linguistic context is undercut, however, by the transhistorical concept of desire on which Tanner relies. Clarissa criticism moves away from psychology to textual play when William Beatty Warner describes the ambiguity of the text, concluding that "rape is the most cogent response to Clarissa's fictional projection of herself as a whole unified body." Reading "Clarissa": The Struggles of Interpretation (New Haven: Yale University Press, 1979), p. 67.

11 Terry Eagleton responds sharply to "the truly reactionary nature of this [Warner's] type of 'deconstructionist radicalism,' once divorced from the social and political contexts it so characteristically finds hard to handle." The Rape of Clarissa: Writing, Sexuality, and Class Struggle in Samuel Richardson (Minneapolis: University of Minnesota Press, 1982), p. 67. Terry Castle argues, in response to Warner's poststructural rhetorical analysis, that "the excruciating situation that Clarissa dramatizes is that a rhetorical system is not 'powerful' unless grounded in political power." However, exactly what sort of political power is being discussed and exactly who is wielding it remains obscure. Clarissa's Ciphers: Meaning and Disruption in Richardson's "Clarissa" (Ithaca: Cornell University Press, 1982), p. 25.

12 Armstrong, p. 4. Part of the difficulty may result from her reliance on Rousseau's $D u$ contrat social (1762), a work published two decades after the appearance of Richardson's first novel, rather than on the earlier British articulations of the social contract, which routinely analyse political authority in terms of questions of gender and authority in the household (pp. 30-34). 
specifically mention Habermas, Carol Kay nevertheless lays the groundwork for a Habermasian critique of Richardson's project through her analysis of Richardson in terms of Hobbes's and Hume's writings on government power and private counsel. ${ }^{13}$ Similarly, Toni Bowers suggests that, in Clarissa, even motherhood is represented in the language of public politics. ${ }^{14}$

In a recent study of eighteenth-century epistolary fiction, Elizabeth Heckendorn Cook reiterates Armstrong's suggestion that Richardson's work plays a vital role in helping to construct what we will later assume to be natural differences between the public and domestic spheres; she also follows Kay's lead in analysing the connection between humanistic discourse and public power. In particular, Cook describes how epistolarity, or the letter form, helps to create the ideology of affective humanism that Habermas describes in his analysis of the public sphere:

An "inner realm" that follows its own laws and is inherently free from extrinsic purposes, especially from economic considerations or constraints, found its discursive mode in the familiar letter and its epistemological model in the idea of a universal, transparent language of the expressive body, which offers a window onto the heart. ${ }^{15}$

Cook also observes that although Habermas at times attempts to distinguish a literary public sphere from the political public sphere, his focus is in fact the political public sphere, while her focus is on "the transnational ideal of a literary public sphere."16

By contrast, I return to the specific politics of the British public sphere in the 1740s. Acknowledging that at this point in history, political discourse was inevitably connected to narratives about the domestic family, I develop and refine Habermas's theory about the relationship between the literary and political public spheres.

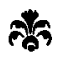

Although the family has been an analogy for the state since the time of Aristotle, the analogy was revived with enthusiasm during the seven-

13 Published one year before Structural Transformation became readily available in English, Kay's work suggests the way in which Richardson routinely translates political criticism into a discourse of morality, thus anticipating the interconnection that Habermas makes between affective humanism and the public sphere (pp. 123-93).

14 Toni Bowers, The Politics of Motherhood (Cambridge: Cambridge University Press, 1996), pp. 196-224.

15 Elizabeth Heckendorn Cook, Epistolary Bodies: Gender and Genre in the Eighteenth-Century Republic of Letters (Stanford: Stanford University Press, 1996), p. 93.

16 Cook, p. 11. 
teenth century as commentators from James I to James Tyrrell sought to justify either the obligation to obey or the right to resist the monarch. ${ }^{17}$ Thus a novel whose author claims in the preface to "caution parents against the undue exertion of their natural authority over their children in the great article of marriage" must be understood as having rich political resonance.

Since 1680, when Robert Filmer's Patriarcha appeared posthumously in response to the first Exclusion crisis, the hierarchical paternalistic household became aligned with attempts to keep the Stuarts on the throne; John Locke's Two Treatises of Government (1689) vindicated a parliamentary monarchy by correcting Filmer's interpretation of the first household: God did not grant dominion of the earth solely to Adam, but granted sovereignty jointly to Adam and Eve. Although this metaphorical dispute over shared power in the household may have seemed anachronistic by the 1740 s, the Parliamentary Revolution of 1688 had neither eliminated traditional belief in divine right nor silenced debates about it in the public sphere. ${ }^{18}$ In fact, discussions about the structure of the state continued well into the eighteenth century and were revitalized particularly when the Jacobite uprisings of 1715, 1719, and 1745 threatened the stability of the crown. When Clarissa describes Lovelace as a tyrant and when Mr B. refers to Pamela's letters as "treasonous papers," we should hear echoes not only of Jacobite cabals surrounding the final attempt of 1745 , as Morris Golden has persuasively argued, but also of earlier debates over social contract theory which were marked by discussions of tyranny in the household. ${ }^{19}$

One obstacle to interpreting the specific political discourses that permeate Clarissa is that even in some of the more sophisticated twentiethcentury criticism, it remains a commonplace to dismiss Anna Howe as a person; she is viewed "more as an extension of Clarissa herself than as a separate individual." 20 Yet, viewing Anna as merely the psychological

17 For full details of this evolution in political theory, see Constance Jordan's excellent article, "The Household and the State: Transformations in the Representation of an Analogy from Aristotle to James I," Modern Language Quarterly 54:3 (1993), 307-26.

18 Martyn P. Thompson, "The Reception of Locke's Two Treatises of Government 1690-1705," Political Studies 24:2 (1976), 189. Critical interest in Locke's Two Treatises did not begin in eamest until the first decade of the eighteenth century: the work itself did not sell particularly well in the 1690s but became increasingly popular throughout the eighteenth century (p. 184).

19 Morris Golden, "Public Context and Imagining Self," SEL 25 (1985), 575-98. Eaves and Kimpel refer to Richardson's thorough knowledge of Locke's theories of education and his at least cursory knowledge of Shaftesbury, Mandeville, Bolingbroke, Hartley, Hume, and Berkeley (p. 571).

20 Wolff, p. 131. Watt and Eagleton make similar observations. 
dark side of Clarissa's own personality prevents us from taking seriously the political content of the highly rational exchange between the two women friends. While theirs is theoretically a private exchange of letters, it is also, rather unexpectedly, an exchange in which two women debate Clarissa's relationship to her family in language that recapitulates the public sphere exchanges from the 1680s and 1690s between the proponents of divine right and the proponents of social contract theory.

Richardson's own political stance, confusingly characterized by his bragging about his father's support for the Duke of Monmouth in a letter to Johannes Stinstra ${ }^{21}$ and by his involvement in printing some Jacobite-influenced issues of the True Briton, is hard to locate within a standard binary distinction between Tory and Whig. As Duncan Eaves and Ben Kimpel suggest, he is opposed to any abuse of power that verges on tyranny, whether in the hands of Tories or Whigs..22 Margaret Anne Doody has pointed out the difficulty of deciding whether Lovelace and Mr B. are portraits of Tory tyrants or Whig abusers of governmental control. Her conclusion is that Richardson's novels should be interpreted as "a discourse about power," particularly about the power of abusive, censoring government. ${ }^{23}$ In so far as the abusers of power in Richardson's ouvre are not central figures in government, but private men and heads of household, it makes sense to turn to the political discourses that link state power to household power if we are to understand the precise criticism of power that Richardson's novels provide. Although Richardson's novels certainly nurtured the affective humanism that Habermas ascribes to the literary public sphere, they also demonstrated how unresolved conflicts about gender and authority, disregarded by increasingly abstract political treatises, were being mediated and re-evaluated through the domestic scenarios of eighteenth-century fiction.

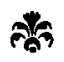

In the second part of Pamela, Mr B. explains, "I think the distinction of whig and tory odious; and love the one or the other only as they are honest and worthy men: and have never (nor ever shall, I hope) given a

21 Letter of 2 June 1753, Selected Letters, p. 228.

22 Richardson's suspicion of monarchs who might be tyrants and his support of the public's right to overthrow these is evident in the 1724 issue of the True Briton, for which Richardson was probably the printer and which resulted in a trial of treason for the publisher: "Englishmen would do well to beware of a 'future' possible king who, being easy and inactive, might 'permit every Man in his Court to be a Tyrant but Himself.' " For a summary of issues 5 and 7 (17 and 24 June 1724), see Eaves and Kimpel, pp. 26-29.

23 See Margaret Anne Doody, "Richardson's Politics," Eighteenth-Century Fiction 2 (1990), 119. 
vote but what I thought was for the public good, let either whig or tory propose it" (1:365). Like his reformed rake hero, Richardson was less interested in partisan politics than in a broader debate about obedience and authority, a debate he returns to through the domestic metaphors that had been implicated in political discourse since the $1680 \mathrm{~s}$, when Richardson's father first pledged support to the Duke of Monmouth.

As Golden has shown, anxieties and debates about the final Jacobite attempt on the English crown (1744-45) permeated London during the years when Richardson was drafting Clarissa. And while many of the original tracts in support of social contract theory-by writers such as James Tyrrell, Algernon Sidney, and William Atwood-had ceased to be in print by the early eighteenth century, Locke's Two Treatises of Government became increasingly popular as the eighteenth century progressed, and the anonymous Judgement of Whole Kingdoms and Nations (1710), an essentially plagiarized abridgment of Locke's Treatises, became one of the best-selling pamphlets in eighteenth-century Britain, as the country gradually came to accept the principles of parliamentary monarchy and contract theory. ${ }^{24}$ It might be logical, therefore, to propose that Richardson, as a loyal supporter of the Revolution of 1688 , was simply recapitulating the arguments of social contract theory in order to assist popular understanding of it. His critique of power, however, is always multivalenced, and his novel provides as much a critique of social contract theory as a vindication of it.

In Clarissa, we can identify a recapitulation of an older formulation of the debate about obedience and authority, characterized specifically by a contrast between a patriarchal and a contractarian version of the domestic household. In the face of tyranny, Clarissa articulates an ideal of obedience traditionally espoused by proponents of absolute monarchy and by those retaining Jacobite loyalty during the final succession crisis in the mid-1740s. "My duty," she explains, "will not permit me so far to suppose my father arbitrary" (p. 95). Although this is delivered in a bitterly sarcastic speech, Clarissa does intend to follow the letter of patriarchal tradition-which means obeying her father, but not her increasingly tyrannical brother.

This attitude does not mean, as Florian Stuber claims, that "Clarissa ... clings to an idea of what her father should be ... no matter what he actually does." ${ }^{25}$ She is aware that her father is unjust or she would not

24 Richard Ashcraft and M.M. Goldsmith, "Locke and Revolution Principles," Historical Journal 26 (1983), 773-800: 789.

25 Florian Stuber, "On Fathers and Authority in Clarissa," SEL 25 (1985), 565. 
consider escaping with Lovelace; however, the principle of divine right theory means that the monarch is always right, even when he acts tyrannically. Her deferential language corresponds to dicta in Robert Filmer's Patriarcha: "the Father of a family governs by no other law than by his own will." Filmer continues, "Kings keep the Laws, though not Bound by them."26 Under this rule, which governs the whole Harlowe family, it would be treasonous for a daughter even to give the impression of disagreeing with her parents. After a negotiating session with Clarissa, in which they debate whether she should respond to one of Lovelace's letters, Mrs Harlowe, pleased with her daughter's honesty and compliance, shows her appreciation by agreeing to conceal Clarissa's original disagreement: "It shall not be known that you have argued with me at all" (p. 96). In this extremely literal version of patriarchal divine right, even voicing differences with authority is considered treasonous.

By contrast, Anna Howe espouses the recognizable tenets of social contract theory with such enthusiasm that she seems to have no doubt about their relevance to the dependent situations of Clarissa and herself. In the epistolary exchanges between the two friends, she voices the same objections to arbitrary authority that were voiced by contract theorists in their arguments to exclude James II from the throne in 1688 and that were alluded to in every subsequent statement of social contract theory published in the eighteenth century. "AUTHORITY!" she declares, "what a full word is that in the mouth of a narrow-minded person, who happened to be born thirty years before one!" (p. 85). Anna is willing to disobey her own mother and order a carriage herself to help Clarissa escape, rather than see her friend fall into Lovelace's clutches. Clarissa, however, refuses this seemingly reasonable offer on the grounds that it would force Anna to disobey her own mother, a disobedience for which Clarissa could not countenance being responsible. Yet Anna continues to challenge Clarissa's perception of her own family: "Another would call your father a tyrant, if you will not" (p. 132-33).

In structuring the exchange between Clarissa and Anna as a quasipolitical debate, Richardson is clearly not interested in having either the divine right or the contractarian position triumph: each demands the reader's respect. On the other hand, in pursuing a political analysis through exchanges about domestic oppression, Richardson is able to call our attention to what is ignored in a binary political argument, that is, those voices which are simply omitted. As recent feminist critics of early liberal political theory have observed, the first proponents of

26 Robert Filmer, Patriarcha, in Patriarcha and Other Political Works of Robert Filmer, ed. Peter Laslett (Oxford: Basil Blackwell, 1949), p. 96. 
a parliamentary monarchy seem consciously to have written women out of the discourses of civil liberty. Carole Pateman argues that the idea of translating power from a patriarchal monarchy to a fraternal or parliamentary sharing of power evolved in tandem with the exclusion of women from the new fraternal power structure and the reinforcement of their purely domestic responsibilities in the household. The newly articulated social contract therefore depended on a prior sexual contract. She explains that "the story of the social contract is treated as an account of the creation of the public sphere of civil freedom. The other, private, sphere is not seen as politically relevant." 27

To understand Pateman's analysis, we need only consider that when John Locke defended the idea of the social contract in his Two Treatises and explained that when God granted dominion of the earth to Adam, he designated Eve as joint monarch: "as many Interpreters think with reason, that these words were not spoken till Adam had his wife, must not she be Lady, as well as he Lord of the World?"28 British social contract theorists, while not concerned with the household per se, originally located their argumentative linchpin in an unexpectedly modern vision of shared power in the family. However, despite this frequent analogy with the family, social contract theorists never intended to challenge a wife's presumably "natural" subordination in the household, which Locke describes in a subsequent paragraph as "no other Subjection than what every wife owes her husband." 29

In 1706, Mary Astell, a High Church Tory, responded to the original framers of the social contract by asking, in the preface to the third edition of her Some Reflections on Marriage, "if Absolute Sovereignty be not necessary in a State, how comes it to be so in a Family?"30 Similarly, Daniel Defoe portrayed the heroines of his novels Moll Flanders (1722) and Roxana (1724) struggling valiantly against male heads of household (whether husbands or employers) who seduce and desert them. In the early 1740s, Eliza Haywood asserted that her domestic anecdotes were actually more political than were parliamentary squabbles, which she likened to "the Knots Children tye at School in Packthread." 31

27 Carol Pateman, The Sexual Contract (Stanford: Stanford University Press, 1988), p. 3.

28 Peter Laslett, ed., Locke's Two Treatises of Government (Cambridge: Cambridge University Press, 1960), First Treatise, paragraph 29.

29 Two Treatises, First Treatise, paragraph 48. For further discussion of Richardson's complex attitude towards maternal authority, see Kay, pp. 166-67.

30 Some Reflections on Marriage (London, 1706), in The First English Feminist, ed. Bridget Hill (New York: St Martins, 1986), p. 76.

31 The Female Spectator, 4 vols (London, 1745), 2:124. 
The contradiction surrounding women's position in the social contract may explain why, once each succession crisis was over, references to the family were less frequent in descriptions of the social contract. By the 1740s, David Hume was writing philosophical essays on the original contract between citizen and monarch that do not mention the family. In his essay "Of Passive Obedience" (1752), Hume attempts to mediate traditional disagreements between rights-based and obedience-based models of government by suggesting that "both these systems of speculative principles are just." His only reference to the familial basis of authority refers to the absurdity of believing "the consent of the fathers to bind the children, even to the most remote generations"; 32 he overlooks the fact that since 1680 many arguments against passive obedience were grounded not in the rights of sons but in the rights of women to disobey tyrannical or abusive husbands. In 1767 Adam Ferguson refers to the family only once in his History of Civil Society, and then to a foreign seraglio. In striking contrast to the increasingly abstracted accounts of liberal political theory, Richardson and other eighteenth-century British novelists uphold the method of Tyrrell's Bibliotheca Politica (1694) and of Locke's still-popular Two Treatises by reasserting the metaphorical relationship between power relations in the family and power relations in the state.

The epistolary argument between Clarissa Harlowe and Anna Howe, then, may be viewed as responding to a discourse of civil liberty that by 1740 no longer routinely utilized the metaphors of the family on which it had originally relied (although such metaphors would later be reintroduced during the political tensions of the French Revolution, as, for example, in Burke's Reflections on the Revolution in France). Clarissa's highly traditional articulation of the theory of divine right rejects the fraternal sharing of power that Pateman describes as underlining the social contract. Rather like royalist proto-feminists Mary Astell in 1700 and Olympe de Gouges in 1791, Clarissa seems to recognize that a fraternal sharing of power will be of no benefit to the sisters in a family or to the dependent women in a nation.

\section{ล้อง}

As a conventionally moralistic thinker, of course, Richardson would not have challenged the logic of abstraction that limited public debate to

32 David Hume, Essays, Moral Political, and Literary in David Hume, The Philosophical Works, 4 vols, ed. Thomas Hill Green and Thomas Hodge Grose (Darmstadt: Scientia Verlag Aalen, 1964), 3:444, 447. 
propertied men. In an oft-cited contribution to a Rambler, in 1751, he mocks the "ladies who frequent those publick places," who "are not ashamed to shew their faces wherever men dare go," or "who shall laugh loudest on the publick walks," ${ }^{33}$ leaving no doubt about his agreement with the relegation of women to the domestic sphere. At the same time, however, in his private correspondence, which was "chiefly with Ladies," he applauded the private contributions of women that are routinely excluded from public debate:

I am envied, Sir, for the Favour I stand in with near a Score of very admirable Women, some of them of Condition; all of them such as would do Credit to their Sex, and to the Commonwealth of Letters, did not their Modesty with-hold them from appearing in it. ${ }^{34}$

Cook calls attention to the fact that for all his solicitation of suggestions from his readers, Richardson rarely heeds the proffered advice: "Like Clarissa's God, Richardson is reluctant to permit his readers to depend for epistemological and moral certainty upon any but himself." 35 Nevertheless, despite his approbation of all that is modest in a woman and despite his reluctance to take the advice of the women whom he describes as a potential asset to the "Commonwealth of Letters," it is evident that Richardson is keenly aware of the loss that ensues from keeping women's superior rationality out of the realm of public debate.

If Richardson's female characters represent an ironic feminization of the masculine debate in the public sphere, Richardson's depiction of Clarissa's traditional paternalism helps us to understand and criticize what Habermas would describe as eighteenth-century affective mythology:

The status of private man combined the role of owner of commodities with that of head of the family, that of property owner with that of "human being" per se. The doubling of the private sphere on the higher plane of the intimate sphere ... furnished the foundation for an identification of those two roles under the foundation of the "private." 36

Habermas further explains that the sentimental doubling of the propertied bourgeois man for "man" in general may not have been mere capitalist ideology: "The rational-critical debate of private people in the salons,

33 Rambler 97 (19 February 1751), reprinted in The Works of Samuel Johnson (New Haven: Yale University Press, 1969), 4:158.

34 Letter to Johannes Stinstra, 2 June 1753, in Selected Letters, p. 234

35 Cook, p. 28.

36 Habermas, pp. 28-29 
clubs, and reading societies was not directly subject to the cycle of production and consumption." ${ }^{37}$ We see here how the literary public sphere contributed to the genuine sense of universal humanity that helped private individuals view their social relationships in terms other than hierarchical class relations.

Habermas does not, however, acknowledge that "man" may refer not only to men of superior rank but to citizens in general, male or female. In the case of gender difference, by contrast, the literary public sphere did not blur the distinctions between the sexes, but highlighted them. Rather than obscuring social differences caused by gender, eighteenth-century novels such as Clarissa specifically called attention to the difference that gender makes in relations of power. For all her espousal of paternal over fraternal rights, Clarissa emphasizes that there may be a greater power struggle between individual men and individual women in the household than there ever is between a propertied male and his representative in Parliament. When she cries to Lovelace, "permit me the freedom which is my birthright as an English subject" (p. 934), Clarissa emphasizes that as an Englishwoman she has been brought up to believe that the discourse of universal liberty applied to individuals in general, not to men only. ${ }^{38}$ Lovelace's abuse of power is extra-familial, since he and Clarissa are not married, and yet the way in which their relationship echoes the characteristics of an abusive marriage (the confined physical setting, the arguments, the passive aggressive behaviour) calls into question the capacity of family structure to guarantee the affective humanism that Habermas claims was generated by Richardson's $œ u v r e$.

When Clarissa is emotionally alienated from both her mother and her sister and desperately craves the affections of Lovelace's relations, he mocks the humanitarian ideal of the domestic family by tricking Clarissa with paid counterfeits of his female cousins. Richardson's location of the supposedly private action between Lovelace and Clarissa in the rented abodes of brothels and public houses further suggests that there is no such thing as a family space of potential human contact not controlled by the legal and economic power that males retain inside and outside the household. Clarissa's last will and testament, which defines her rhetorically as a martyr to her family, is calculated to call attention to the difference between her affective loyalty to her family (to whom she legally wills most

37 Habermas, p. 160 .

38 This is consistent with Florian Stuber's observation that in a novel devoid of strong paternal figures, Clarissa becomes an example of prudent, mature masculine power: "In her Will, Clarissa uses power, but with restraint, and only for the purposes of love and nurture. She seems an ideal secular authority. The mind is father to the deed. Or, if I can break through the sexism inherent in the metaphor, Clarissa herself becomes a Father" (p. 574). 
of her separate property, which her father and her brother had always retained under their control) and the real emotional support provided by her beloved Mrs Norton, whose care she describes as second to "the piety and care of my ever-honoured and excellent mother" (p. 1415) and to whom she wills an unexpected (and subsequently contested) six hundred pounds.

The ideal of a loving, caring family-fundamental to a Lockean concept of liberal political theory and fundamental to Habermas's notion of affective humanism-is pictured by Richardson not in the image of the Harlowe family but in the union between Anna Howe and her persistent lover, Hickman. Although Anna repeatedly insists on her "aversion to all men: to him: to matrimony" (p. 1456), she eventually marries Hickman, following both Clarissa's advice and her own mother's wishes. In contrast to Clarissa's notion that family harmony can only be achieved through old-fashioned patriarchalism, Anna's marriage proves that her modern contractarian principles are the most plausible route to an equal union. The narrator tells us that "there is but one will between them; and that is generally his or hers, as either speak first upon any subject, be it what it will"' (p. 1492).

In taking contract theory to its logical extreme, Anna Howe has managed to rewrite Genesis so that Locke's hypothetically updated version of the family (in which husband and wife share equal dominion in the household) actually applies to her own marriage. Furthermore, in establishing a strong contrast between "his" and "hers," this passage undercuts the public sphere ideal of a genderless, universal individual and emphasizes instead that a true contract between non-abstract individuals must grant as much weight to the female will as to the male will. Thus, according to Armstrong, even as the early British novel was emphasizing the importance of gender difference over other political difference, and, according to Habermas, was serving to generate affective humanism among propertied men, it was also offering a corrective supplement to the abstract debates of the political public sphere.

\section{คิำ}

Unlike the monologic account of Pamela, in which Pamela's own letters provide the dominant voice, the thoroughly dialogic interplay between Clarissa and Anna in Richardson's second novel represents an exchange that might take place in a coffee-house debate about politics; Clarissa herself even at one point challenges her brother to a debate. Moreover, Richardson calls our attention to the extreme rationality of Clarissa and Anna: neither ever yields to the sort of passionate rage 
that marks Lovelace's letters to Belford; each expresses her position thoughtfully and dispassionately. Richardson's choice then-to place the most rational debate in his novel in the voices of politically powerless women-emphasizes the irrationality of excluding women from public debate.

This is not to say that Richardson would want women running for public office or otherwise avoiding their duties as wives and mothers. If we follow the example of Pamela-providing her private letters for public circulation and eventually, at the urging of her husband, writing a type of conduct book for child-rearing-we can understand the ways in which Richardson might have envisioned women entering the literary public sphere through a commentary on the domestic sphere. We must remember, however, that in the second part of the novel, Pamela not only becomes a potential author, she also enacts a public courtroom scene when she cleverly puts herself on trial for her husband's act of adultery against her. This scene, in which a woman in the domestic sphere manipulates a public figure (her husband) by a private, fictional dramatization of a public court, confounds the difference between the public and domestic spheres. Richardson ultimately shows how women could criticize the political sphere (or at least the adulterous dishonesty of a public member of the House of Parliament) through rational discourse within the domestic household.

Like those who today insist on the relevance to a politician's public career of "private" acts of sexual harassment, Richardson's heroines insist on the significance of a public man's private acts of oppression. In so doing, they challenge the separation of the literary from the political public sphere. Richardson obviously designated the emergent novel as a genre that could challenge the tacit underpinnings of the political public sphere and be undertaken equally well by women as by men. ${ }^{39}$ Furthermore, his own novels challenge the assumption that the household should serve only as an arena that humanizes the bourgeois citizens' conceptions of themselves as human and not as a category that is itself worthy of public scrutiny.

Beyond the implicit debate about government structure that takes place in Clarissa and Anna's "treasonous" correspondence, Richardson has Clarissa go out of her way to make public what would otherwise have been seen as a personal or domestic crime-her rape. In Richardson's first novel, when Pamela taunts Mr B. with the possibility of her gaining revenge on him, Lucretia-style, should he succeed in raping her,

39 See notes on Richardson's encouragement of or influence on Charlotte Lennox in Duncan Isles's appendix to The Female Quixote (1752; Oxford: Oxford University Press, 1989), pp. 419-28. 
she is probably more serious than he believes, but his quick allusion to the romance comedy he feels their story will tell erases the memory of Lucretia's tragic fate, just as it erases the political reference to the overthrow of the Tarquin monarchy that resulted from that earlier, presumably private, act of rape. By contrast, Richardson's tragic heroine, Clarissa Harlowe, rather than simply stabbing herself, as Lucretia did after mutely publicizing her violation, and as Lovelace fears she might do, allows herself to die gradually, as if willing her own slow physical disintegration while she readies the legal tenets of her last will and testament.

In tracing the history of eighteenth-century rape law, Frances Ferguson explains that while rape was theoretically considered a crime that should be prosecuted publicly, women did not often dare to prosecute rapists. ${ }^{40}$ Yet, while Lovelace repeatedly stresses that Clarissa should save herself the shame of her rape's being known, she continues to publicize what, as in the story of Lucretia, has always been both a deeply personal and an essentially political offence. In Richardson's time, of course, the politics of rape would have been defined in terms of the violation of a husband's unique right to his wife. Richardson, however, redefines both the politics of rape and the significance of making such a crime public.

Clarissa talks candidly of her experience to the strangers from whom she rents a room during the last period of her life; she writes to Lovelace's female cousins, making public his actions. By thus publicizing the most intimate details of her private oppression, Clarissa expands the idea of the public sphere from periodical and coffee-house debates among propertied men to include gossip among neighbours and boarding-house keepers as well as epistolary exchanges between aristocratic women. In refusing to present her case in a public court of law, she implies that the public system of justice would not protect her rights as a rational citizen as well as would an expanded public sphere that included the voices of other concerned and empathetic women.

Clarissa not only expands the notion of who should be included in the public sphere, but she also enlarges the range of subject matter appropriate for discussion. By insisting on publicizing a crime that others want her to contain within the domestic sphere of the household, Clarissa suggests that domestic violence is as worthy of public scrutiny as is state tyranny. Anna Howe and Lovelace both believe that Clarissa should stop publicizing her rape and simply marry her rapist (thus containing Lovelace's criminal act within the ex post facto ceremony that legally nullified the 
crime). Lovelace believes that the tragic ending on which Clarissa insists could be avoided through its containment either as domestic comedy or romance: "Is not the catastrophe of every story that ends in wedlock accounted happy, be the difficulties in progress to it ever so great?" (p. 944). Both Lovelace and Anna wish to render the highly political tragedy of Lucretia into the domestic romance of Pamela. Clarissa, however, will write her own tragic story against the grain of romance convention, using the form of tragedy (traditionally about crises in the nation state) to thwart the domestic containment of a romance ending.

\section{คูล}

By publicizing her rape and making public, through her last will and testament, the hypocrisy of the supposed benevolence of her paternal family, Clarissa redefines the public sphere not merely as a means of criticizing tyranny in the state but as a means of protesting against abuses of power in the household as well. ${ }^{41}$ By framing his critique of the public sphere within a work of fiction, Richardson thus insists on the political relevance of the literary public sphere. Ultimately, however, the novel's tragic ending contains Richardson's challenge to the political public sphere within a pessimism that would have paralysed real reform of women's position. Although Anna Howe's story allows for a certain optimism, its narrative subordination to the central tragedy guarantees the reader's focus on the fact that Clarissa has few morally viable options other than death. Richardson's Clarissa thus stands as testimony both to the contradictions inherent in the universalistic discourse of the bourgeois public sphere and to the social structures that would obstruct and delay its ultimate self-transformation. ${ }^{42}$

By resurrecting the highly gendered discourse of earlier debates about authority and obedience, Richardson has managed to challenge the emer-

41 While I suggest ways in which Clarissa manages to make her story public, Cook focuses on Clarissa's failure to find "a narrative agora: an open public space where she can tell her story." For Cook, Clarissa is "transformed into a personification, one circumscribed by the more powerful narrative of eighteenth-century male literary authority." Epistolary Bodies, p. 112. While Clarissa's political message is ultimately subordinated to the message implied by her tragic martyrdom, her words nevertheless enter the public record through Richardson's novel. Certainly her late twentieth-century readers have been educated by their transgressive potential.

42 Habermas has recently described the potential for self-transformation inherent in "the universalistic discourses of the bourgeois public sphere." See "Further Reflections on the Public Sphere," in Habermas and the Public Sphere, ed. Craig Calhoun (Cambridge: MIT Press, 1992), p. 429. He does not fully explain, however, how a critique of the exclusionary tendencies of the public sphere was being scripted by the same writers whom he cites as helpful in constructing its affective mythology. Furthermore, simply acknowledging that the public sphere had a potential for self-transformation does not begin to acknowledge the role the novel might have played in both enabling and obstructing such a transformation. 
gent ideal of a public of letters that excludes the insights of the women of genius who compose the marginalized, but still viable, "commonwealth of letters." If Clarissa's discourse within the literary public sphere challenges the hegemony of the bourgeois public sphere only to be silenced by the tragedy of her demise, the novel's own potential for effecting social transformation founders on its reception (to which Richardson himself certainly contributed) as merely a conduct manual about marriage. While Richardson's most famous tragedy interrogates the logic by which women were excluded from the political public sphere, it simultaneously helps, through the power of its moral discourse, to obscure the profoundly political foundation of both domestic fiction and the literary public sphere..$^{43}$

\section{Cleveland State University}

43 The final version of this article owes much to the discussion generated by a shorter version of this essay ("Affective Humanism and the Family: Habermas's Misreading of Richardson") given at a Northeast Modern Language Association panel on Richardson, 20 April 1996. I am indebted to the perceptive comments provided by Carol Kay, Elizabeth Blood, and Teri Ann Doerksen. 